\title{
Research of overburden rocks geological parameters impact to the excavators cutting bodies abrasion in the Most basin conditions
}

doi:10.2478/mape-2019-0035

Date of submission to the Editor: $07 / 2018$

Date of acceptance by the Editor: 08/2018

MAPE 2019, volume 2, issue 1, pp. 356-366

\section{Michal Řehoř}

Vlastimil Moni*

Brown Coal Research Institute j. s. c., Most, Czech Republic

\section{František Helebrant}

Jan Blata

VŠB-Technical University of Ostrava, Czech Republic

\section{INTRODUCTION}

The solving of the Czech Republic Technology Agency TAČR research project No. TH03020368, titled „The optimisation of the shape and material of ground and mining machines research", started in 2018.

The conception of this project is based on key placement of the period of „Realisation and evaluation of long term measurement in situ and laboratory measurement in experimental stands. The target of the measurement is the obtaining of verified data. According of evaluation of these data we will determine the main reasons of the tooth wearing out in different geological conditions. The optimisation and operating testing of the cutting bodies shape and material will be realised after obtaining and evaluation of the results of long term measuring. The methodology of optimum tooth type and of optimum tooth material in different geological situation for mining companies will be realised in the final stage of the project (Moni et al., 2018).

Realisation of experiments with different types of cutting bodies materials in well known, defined and comparable geological and mining condition is necessary for the success of these experiments. It was the reason for solving of the geological situation of the mines Bílina, Vršany and Libouš. The comparison of the Most Basin situation with the important European coal localities is shown in the chapter No 4. This first stage of research project solving is the topic of the article.

\section{METHODOLOGY OF THE RESEARCH}

The Brown Coal Research Institute is working in the field of overburden rocks parameters lots of years. It was gained much information about overburden rocks, hard rocks and sands during long term sampling and laboratory works.

The most important analyses were:

- analysis of crystalline quartz content (chemical and X - RAY analyses)

\footnotetext{
*rehor@vuhu.cz
} 
- analysis of $\mathrm{CaCO}_{3}$ content

- analysis of $\mathrm{FeCO}_{3}$ content

- analysis of compressive strength (MPa)

- penetration analysis

All analyses were realised by research laboratory VÚHU accredited by ČIA according to ČSN EN 150/IEC 17025.

The four main mining localities are situated in the area of the Most Basin, but mining of the overburden rocks was finished in the CSA mine. The research was therefore focused to open pit mines Bílina, Vršany and Libouš. The complex evaluation of overburden rocks important parameters is the result of presented research.

\section{RESULTS OF THE RESEARCH \\ Geological situation of the Most Basin}

The sedimentation in the Most Basin began in the Eocene period when several rather small depressions were gradually filled with gravels, sands and variegated silts and clays. These materials were deposited on mostly weathered basement represented by Cretaceous and Permocarbonicerous sediments and crystalline rocks of the Krušné hory Mts (Burda et al., 2017). Individual depressions are thought to have been functioning most probably as lakes with outlets. This fluviolacustrine sedimentation was during the Oligocene interrupted by volcanic activity which, during the first volcanic phase, caused the formation of the Doupovské hory Mts. and the České středohorí Mts. Together with volcanism some new depressions were formed or the original depressions began sinking to the filled with volcano - detrital material (Mach, 2002; Mach, 2003).

Another interruption of sedimentation is believed to have occurred during the Early Miocene when lakes with outlets and erratic sedimentation were formed (Mach, 2010). More solid products of weathering derived from neovolcanites and the majority of underlying units were deposited during this period. The fine sedimentation was disturbed by supply of coarse detrital material from the south (Mach, 2002a).

Layers of the productive series in the roof were deposited in a shallow whole - basin lake which became gradually overgrown with vegetation due to favourable climatic conditions. Among huge conifers, the trees of genus Taxodium are thought to have been the most abundant. This productive period occurred during the Early Miocene which led to the formation of a thick seam which in the Žatec region, at the southern margin of the basin, was split into several unmineable benches (Rojik, 1996).

Mineral assemblages then originated under the above mentioned conditions and were completely confined to a coal seam and isochronous with the origin of the coal. The origin of mineral assemblages confined to the so - called overlying clays was also affected by the underlying coal seam. These rocks consist of mostly grey and or brown lacustrine aleurolites, i. e. clay sediments with a silty fraction and locally containing huge nodules of clay ironstone (Rajchl, 2006). These sediments were deposited in deeper lake in covering the entire basin in which several streams have emptied (the Žatec delta, the Bílina delta). These overlying layers were affected by second volcanic phase which brought in pyroclastic material.

Quaternary period is characteristic of formation of loess, development of the recent river system and the origin of oxyhumolites during alternating frost penetration of the upper parts of the coal seam at outcrops (Rajchl \& Ulicny, 2000). 
The overburden soils and rocks lying over the coal seam in the research area consists of Libkovické layers of siltstones and complex of sand-clay sediments of the fossil river delta, which together with the coal seams are ranked with the Holešovické layers. These rocks are the source of all types of hard rocks (Pesek et al., 2010; Valasek \& Chytka, 2009).

\section{Geological situation of the Bílina mine}

The upper horizon consists of Quaternary rocks - topsoil, loess and loess loams. These rocks are selectively mined and used during restoration works. Underlying Tertiary horizon consists of brown, grey and grey - brown montmorillonite - illite kaolinite clays and claystone's. The thickness of this layer is about $60 \mathrm{~m}$, it is a result of the lake sedimentation.

The underlying horizon is the main layer of the Bílina mine overburden. It consists of yellow sandy clays and clayey sands. The thickness of this horizon is more than 150 $\mathrm{m}$, it is a result of river delta sedimentation. This horizon is an important source of unmineable inclusions and geological structures with excessive mining resistance.

Thickness of the coal seam is about $30 \mathrm{~m}$. Underlying rocks consist of lower Tertiary grey claystone's and Cretaceous marls (Mach, 2003).

The geological profile of the Bílina Mine is shown in the Figure 1 (Dvorak, \& Mach, 1999), the situation of the Bílina mine overburden cuts is shown in the following photo (Figure 2).

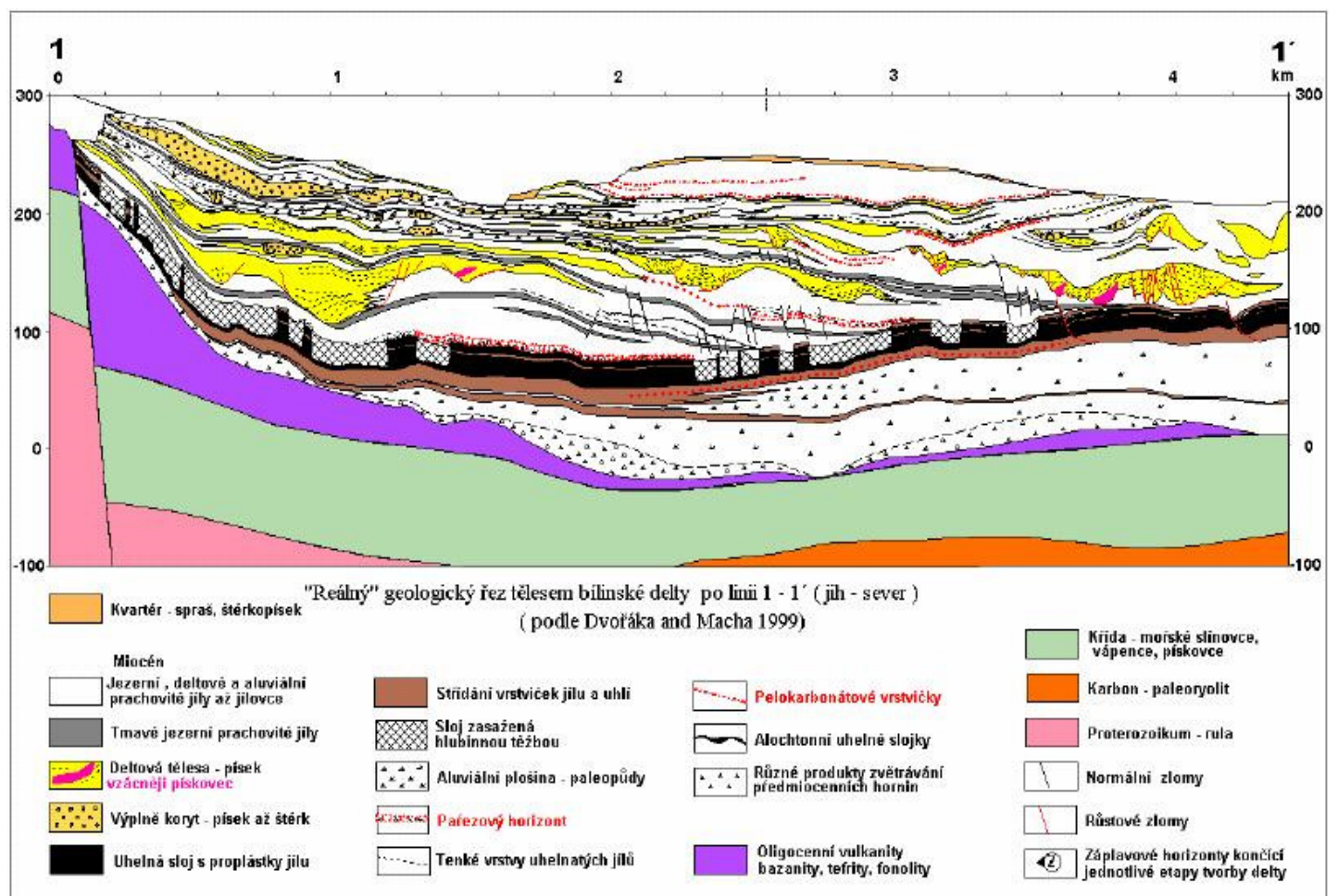

Fig. 1 The Bílina Mine - geological situation of the overburden cuts

Source: (Dvorak \& Mach, 1999). 


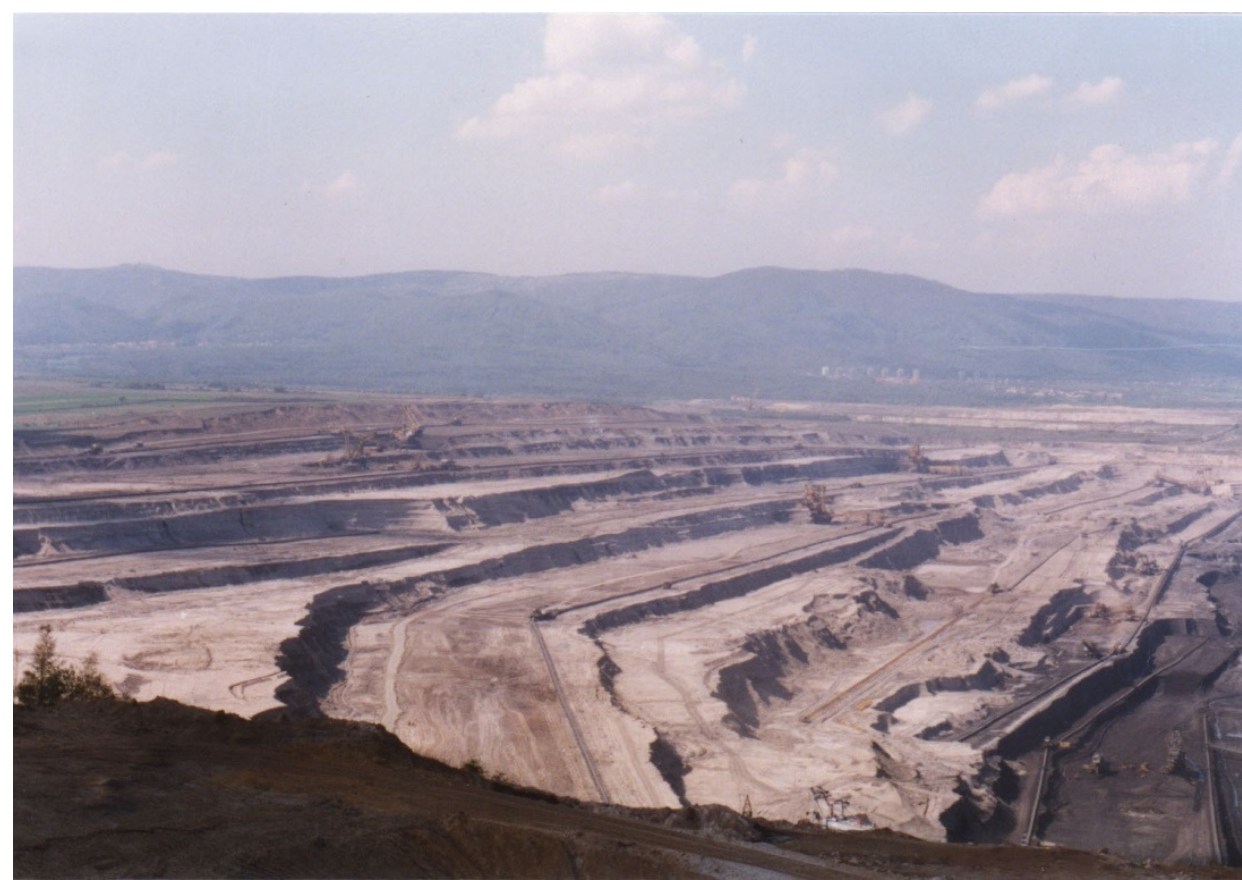

Fig. 2 The Bílina Mine - situation of the overburden cuts

The main types of the overburden rocks are clays, sandy clays and sands. The value of comprehensive strength ranges between 0 (sands) to $2,5 \mathrm{MPa}$, the content of clay minerals ranges between 10 to $70 \%$, the value of density ranges between 1900 to $2050 \mathrm{~kg} / \mathrm{m}^{3}$ and the texture of rocks is layered or clastic.

\section{Occurrence, geological situation and characteristic of hard structures}

Four types of hard structures were discovered during the history of mining in the Bilina mine.

Thin (thickness from 0.1 to $0.4 \mathrm{~m}$ ) small continuous layers of clay with high content of carbonates are the first type of hard structures. These solid-rock positions are problematic for extraction, although mineable with large-scale excavator technologies. The occurrence of this hard rock type is connected with the base of the Neogene brown - grey clays (lake sedimentation).

Pelocarbonatic concretions (thickness from 0.5 to $2 \mathrm{~m}$ ) are the second type of hard structures. These solid-rock inclusions are more problematic for extraction, although mineable with any excavator technologies. The occurrence of this hard rock type is connected with the base of upper Tertiary brown - grey clays (lake sedimentation).

Sandstones with dolomite cement (thickness from 0.5 to $15 \mathrm{~m}$ ) are the third type of hard structures. It is a most frequent and most dangerous hard structure type. This sandstone with dolomitic cement, which reaches up to $30 \%$ volume of solids can reach surface sizes of 100 to $10000 \mathrm{~m}^{2}$ (Mach, 2002a). These solid-rock inclusions are extremely problematic for extraction, blasting is necessary in the majority cases. The occurrence of this hard rock type is connected with yellow sands and sandy clays (river delta sedimentation) (Bily \& Brabenec, 2012).

Sandstones with limonite cement (thickness from 0.5 to $2 \mathrm{~m}$ ) are the last hard structure type. This type is not so danger because of it is quite rare in the Bílina mine overburden cuts (Mach, 2002). The main parameters of the Bílina mine hard structures are shown in the Table 1. 
Table 1

Main parameters of the Bílina mine hard structure

\begin{tabular}{|c|c|c|c|}
\hline Material type & $\begin{array}{l}\text { Sandstone with } \\
\text { carbonate cement }\end{array}$ & $\begin{array}{l}\text { Clay with high content } \\
\text { of carbonate }\end{array}$ & $\begin{array}{l}\text { Carbonate } \\
\text { concretions }\end{array}$ \\
\hline Continuous & no & yes & no \\
\hline Material type (source) & sandy claystone, sands & claystone & clays, claystones \\
\hline Boulders & yes & no & yes \\
\hline $\begin{array}{l}\text { Size distribution }(m) \\
(\min -\text { mode }-\max )\end{array}$ & $\begin{array}{c}0.2-1.5-10 \\
\text { (exceptionally } 15)\end{array}$ & $0.1-0.2-0.4$ & $0.2-0.4-1$ \\
\hline Shape & roundness, slabs & layer & Roundness, slabs \\
\hline $\begin{array}{l}\text { Composition } \\
\text { Mineral A }\end{array}$ & quartz & kaolinite & siderite \\
\hline Mineral B & Dolomite & siderite & kaolinite \\
\hline Mineral C & siderite & quartz & quartz \\
\hline Mineral D & kaolinite & & \\
\hline Density $\left(\mathrm{kg} / \mathrm{m}^{3}\right)$ & 2200 & 2200 & 2500 \\
\hline $\begin{array}{l}\text { Compressive } \\
\text { strength (MPa) }\end{array}$ & 15-40 (exceptionally 60) & $5-15$ & $5-40$ \\
\hline Resistivity $(\Omega \cdot \mathrm{m})$ & 200 & 100 & 150 \\
\hline
\end{tabular}

We started the testing of survey method after finishing of the Bílina Mine hard structures research. The large boulder of sandstone with dolomite cement is shown in the following photo (Figure 3).

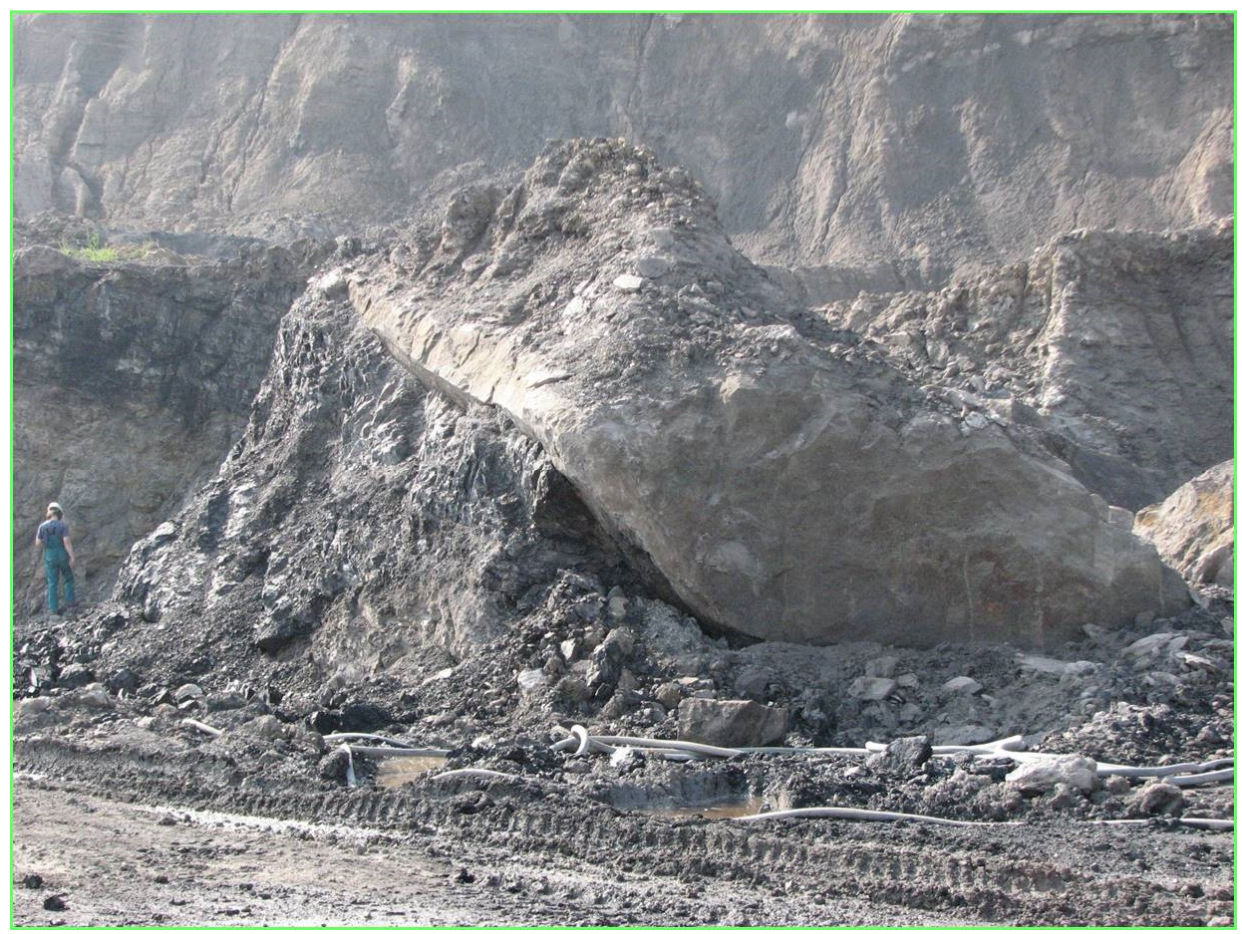

Fig. 3 Boulder of sandstone with dolomite cement

Source: (Dvorak \& Mach, 1999).

\section{Occurrence, geological situation and characteristic of Bílina sands}

Sandy horizons and lenticles are situated under strata of tertiary, brown montmorillonite - illite - kaolinite clays in river delta sediments. The thickness of sandy strata ranges between $5-30 \mathrm{~m}$. The content of the crystalline quartz ranges between $75-90 \%$. The content of crystalline quartz and siderite is increasing according to the depth of sedimentation (Rehor \& Moni, 2016).

The occurrence of the hard rocks in sandy sediments and high level of abrasion of 
these sediments is typical in the Bílina overburden rocks. It is a reason of bad mining conditions of these rocks.

\section{Geological situation of the Vršany mine}

The Vršany mine is smaller than the Bílina mine, but geological situation of this mine is quite similar.

The upper horizon consists of Quaternary rocks - topsoil, gravels and high quality loess. These rocks are selectively mined and used during restoration works. The majority of these rocks are mined these days. Underlying Tertiary horizon consists of brown montmorillonite - illite - kaolinite clays. The thickness of this layer ranges between $0 \mathrm{~m}$ to about $40 \mathrm{~m}$, it is a result of the lake sedimentation (Rehor, 2010).

The upper coal seam is situated under this horizon. The thickness of this coal seam ranges from $0 \mathrm{~m}$ to about $5 \mathrm{~m}$.

The underlying horizon is the main layer of the Vršany mine overburden. It consists of yellow sandy clays and clayey sands. The thickness of this horizon ranges from about $5 \mathrm{~m}$ to about $50 \mathrm{~m}$, it is a result of river delta sedimentation. This horizon is an important source of unmineable inclusions and geological structures with excessive mining resistance (Rehor et al., 2016).

Thickness of the main coal seam is about $30 \mathrm{~m}$. Underlying rocks consists of lower Tertiary grey claystones, yellow sands and Cretaceous marls.

The geological profile of the Vršany mine is shown in the Figure 4, the situation of the Vršany mine overburden cuts is shown in the following photo (Figure 5).

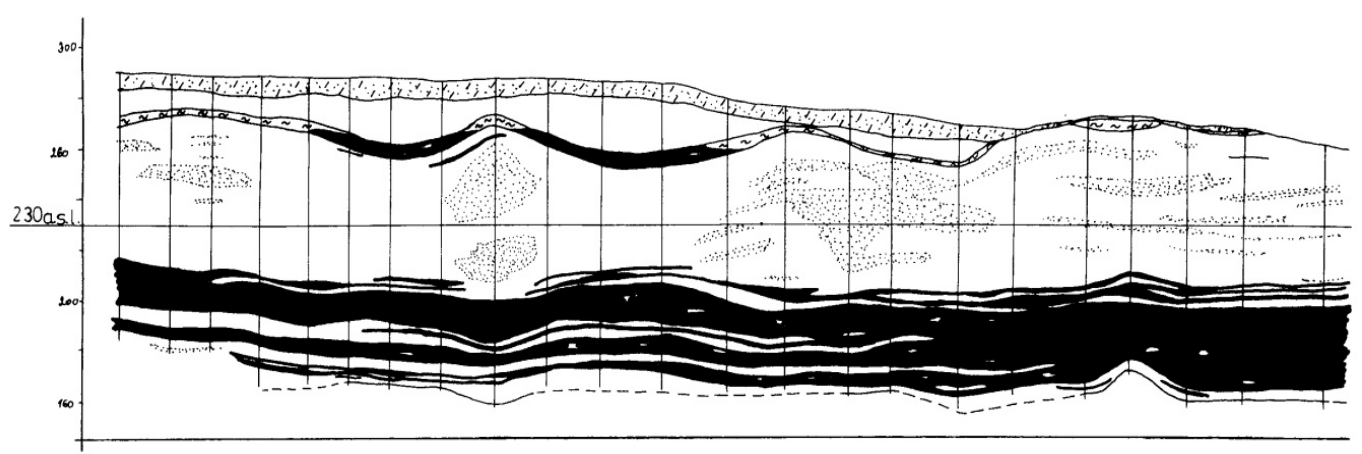

Fig. 4 The Vršany Mine - geological profile

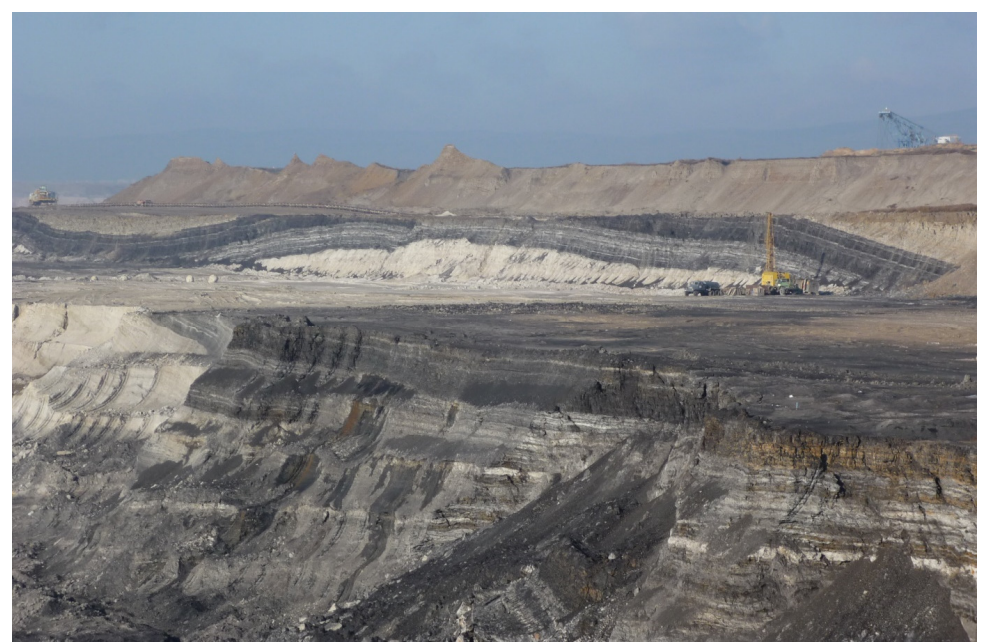

Fig. 5 The Vršany Mine - situation of the overburden cut 
Occurrence, geological situation and characteristic of hard structures

Three types of hard structures were discovered during the history of mining in the Vršany mine.

Carbonate concretions (thickness from 0.2 to $1 \mathrm{~m}$ ) are the first type of hard structures. These solid-rock inclusions are problematic for extraction, although mineable with any excavator technologies. The occurrence of this hard rock type is connected with the base of upper Tertiary brown - grey clays (lake sedimentation).

Sandstones with dolomite cement (thickness from 0.5 to $5 \mathrm{~m}$ ) are the second type of hard structures. It is a most frequent and most dangerous hard structure type. These solid-rock inclusions are very problematic for extraction, blasting is necessary in the majority cases. The occurrence of this hard rock type is connected with yellow sands and sandy clays (river delta sedimentation) (Rehor et al., 2016). Sandstones without carbonate cement (thickness from 0.5 to $5 \mathrm{~m}$ ) are the last hard structure type. This type is not so danger because better parameters (see the Table 2).

Table 2

Main parameters of the Vršany mine hard structure

\begin{tabular}{|c|c|c|c|}
\hline Material type & $\begin{array}{l}\text { Sandstone with } \\
\text { carbonate cement }\end{array}$ & Sandstone & $\begin{array}{l}\text { Carbonate } \\
\text { concretions }\end{array}$ \\
\hline Continuous & no & no & no \\
\hline Material type (source) & Sandy claystone, sands & $\begin{array}{l}\text { Sandy claystone, } \\
\text { sands }\end{array}$ & Clays, claystones \\
\hline Boulders & yes & yes & yes \\
\hline $\begin{array}{l}\text { Size distribution }(\mathrm{m}) \\
(\mathrm{min}-\operatorname{mode}-\max )\end{array}$ & $0.2-1.5-5$ & $0.2-1.5-5$ & $0.2-0.4-1$ \\
\hline Shape & Roundness, slabs & Roundness, slabs & layer \\
\hline $\begin{array}{l}\text { Composition } \\
\text { Mineral A }\end{array}$ & quartz & quartz & siderite \\
\hline Mineral B & dolomite & kaolinite & kaolinite \\
\hline Mineral C & siderite & & quartz \\
\hline Mineral D & kaolinite & & \\
\hline \multicolumn{4}{|l|}{ Mineral E } \\
\hline \multicolumn{4}{|l|}{ Other } \\
\hline Density $\left(\mathrm{kg} / \mathrm{m}^{3}\right)$ & 2200 & 2000 & 2500 \\
\hline $\begin{array}{c}\text { Compressive strength } \\
(\mathrm{MPa})\end{array}$ & 15-40 (exceptionally 80) & $5-15$ & $10-50$ \\
\hline Resistivity $(\Omega \cdot \mathrm{m})$ & 200 & 200 & 150 \\
\hline
\end{tabular}

The situation of the Vršany mine sandstones (after blasting and before crushing) is shown in the following photo (Figure 6). The main parameters of the Vršany mine hard structures are shown in the Table 2.

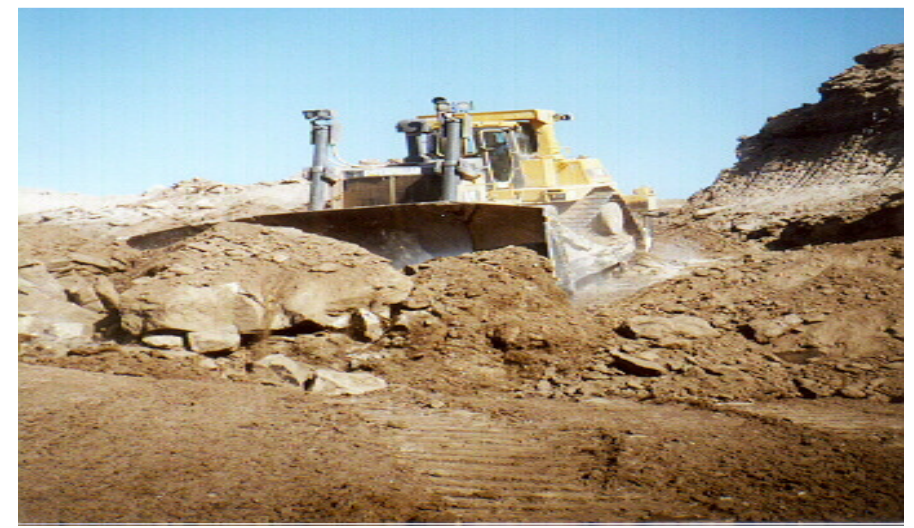

Fig. 6 The Vršany Mine - sandstones with carbonate cement after blasting 
Occurrence, geological situation and characteristic of Vršany sands

Sandy horizons and lenticles are situated under the upper coal seam in river delta sediments. The thickness of sandy strata ranges between 2-15 $\mathrm{m}$. The content of the crystalline quartz ranges between $75-90 \%$. The content of crystalline quartz and siderite is increasing according to the depth of sedimentation.

The occurrence of the hard rocks in sandy sediments and high level of abrasion of these sediments is typical in the Vršany overburden rocks. It is a reason of bad mining conditions of these rocks, but the situation is not so danger as in the case of the Bílina mine.

\section{Situation of the Libouš Mine}

The Libouš mine is situated in the South-Western part of the Most Basin. The main layer of the Libouš mine overburden consists of brown, grey and grey - brown montmorillonite - illite - kaolinite clays. The thickness of this homogenous horizon ranges from $40 \mathrm{~m}$ to $130 \mathrm{~m}$, it is a result of lake sedimentation (Rehor, 2013).

The situation of the Libouš hard rocks is different. We discovered only of these structures. No of than is dangerous. Two types of hard rocks were discovered during historical overburden rocks mining in the northern part of the mine - quartzite in the part of the first overburden cut (fossil land slide) and calcite concretions in the part of the second overburden cut (Pesek et al., 2010). During present mining in the east direction we discovered only rare siderite and calcite (maximum thickness only 0.3 $\mathrm{m})$. There are practically no problems with unmineable inclusions and geological structures with excessive mining resistance these days (Rehor et al., 2017; Zdarsky \& Rehor, 2007). The main parameters of Libouš hard rocks are shown in the Table 3, the situation of the first overburden cut is shown in the following photo (Figure 7).

Table 3

Main parameters of the Libous mine hard structure

\begin{tabular}{|c|c|c|}
\hline horninový typ & $\begin{array}{c}\text { clay with high content of } \\
\text { siderite }\end{array}$ & siderite and calcite concretions \\
\hline Continuous & yes & partially \\
\hline Material type (source) & clay & clay \\
\hline Boulders & no & no \\
\hline $\begin{array}{l}\text { Size distribution (m) } \\
(\min -\text { mode - max })\end{array}$ & $0.1-0.2-0.3$ & $0.1-0.2-0.3$ \\
\hline Shape & strata & strata, blocks \\
\hline $\begin{array}{l}\text { Composition } \\
\text { Mineral A }\end{array}$ & siderite & siderite \\
\hline Mineral B & kaolinite & kaolinite \\
\hline Mineral C & quartz & quartz \\
\hline Mineral D & illite & calcite \\
\hline Mineral E & calcite & \\
\hline \multicolumn{3}{|l|}{ Other } \\
\hline Density $\left(\mathrm{kg} / \mathrm{m}^{3}\right)$ & 2200 & 2400 \\
\hline $\begin{array}{l}\text { Compressive strength } \\
(\mathrm{MPa})\end{array}$ & $5-20$ & $5-40$ \\
\hline Resistivity $(\Omega \cdot \mathrm{m})$ & 80 & 150 \\
\hline
\end{tabular}




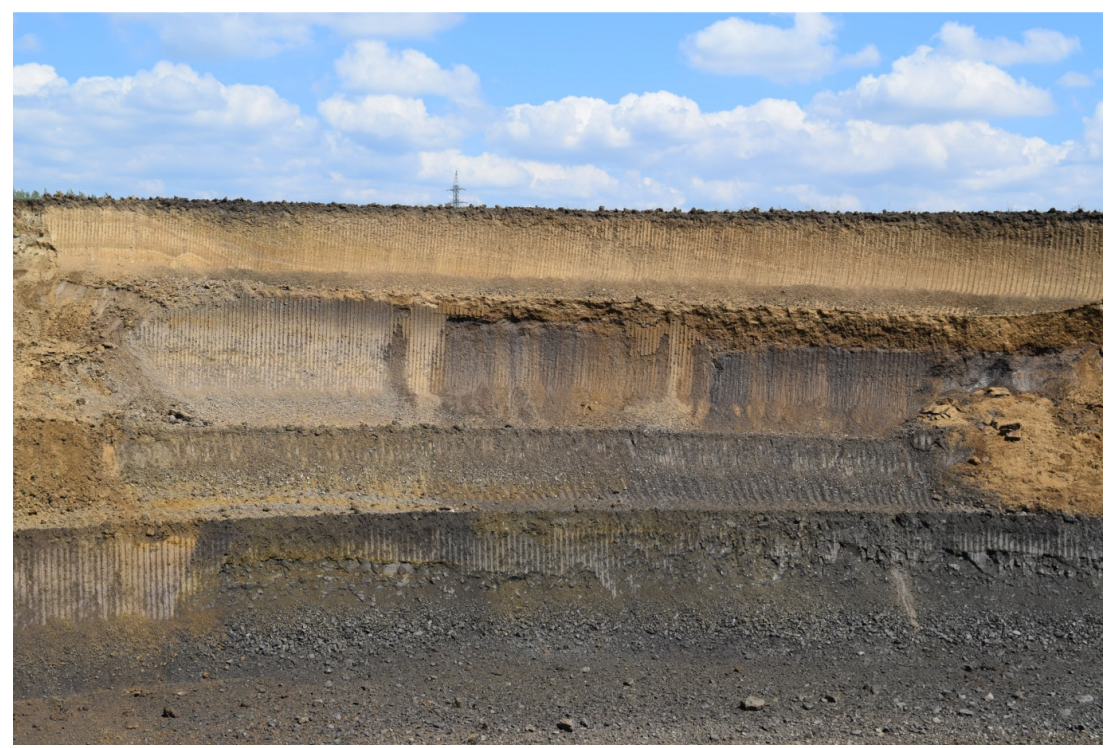

Fig. 7 Situation of the Libous mine first overburden cut rocks

\section{DISCUSSION}

The comparison of the Most Basin overburden rocks with the situation of the most important European coal basins was the part of presented research. It was evaluated the situation of the Belchatow area (Poland), the Lužice Basin (Germany and Poland), the Rhine Basin (Germany) and the Ptolemais and Megalopolis Basins (Greece) (Vossen, 2006; Poltegol, 2018).

The specific property of the Most Basin is very high content of clay and claystone in the overburden cuts of mining localities. The parameters of these rocks are different because to different content of siderite. The main overburden rock of majority of evaluated European coal basins is sand, in the case of Greece basins it is calcite too. The hard rocks of the Most Basin are siderite and quartzite, in next localities it is quartzite, calcite, crystalline boulders (Belchatow) and siderite (Poltegol, 2018).

These differences are very important for the evaluation of the overburden rocks abrasiveness and the impact to the optimum excavator construction. It is the reason of the necessity of the research aimed to the Most Basin overburden rocks parameters.

\section{CONCLUSION}

Evaluation of the geological situation of the Bílina, Vršany and Libouš mines (mining of the overburden rocks in the ČSA mine finished) is the first stage of the solving of the project "The optimisation of the shape and material of ground and mining machines research". The occurrence of sandy strata and the parameters of hard rocks are the most important parameters. The most important used laboratory analyses were the content of crystalline quartz, content of siderite, content of calcite and compressive strength.

Present information about the occurrence and parameters of sands and hard rocks, summarised in this article, are relatively good. I tis based on the results of borehole survey and laboratory analyses.

We discovered big sandy strata (thickness 2-30 m) and the occurrence of different types of hard rocks (thickness $0.2-15 \mathrm{~m}$ ). in the area of the Bílina mine. So Bílina mine 
is the most danger locality from point of view of the excavators cutting bodies abrasion. We discovered quite big sandy strata (thickness 2-12 $\mathrm{m}$ ) and the occurrence of different types of hard rocks (thickness $0.2-5 \mathrm{~m}$ ). in the area of the Vršany mine. So Vršany mine is relatively danger locality from point of view of the excavators cutting bodies abrasion too. The best mining conditions are in the Libouš mine with minimum occurrence of sands and hard rocks.

For need of future research it is possible to observe the similar conditions in first overburden cuts of all localities (with exception of the Bílina mine in the part without occurrence of Libkovice clay horizon). We observe the similar conditions in the clay part of the Bílina first overburden cut and 2-4 overburden cuts of Libous mine and lower overburden cuts of Bílina and Vršany mines.

The results published in this article are only the first step of the research. The most important part of the research will be monitoring of the mining machines loading and cutting bodies abrasion.

\section{ACKNOWLEDGEMENT}

The paper was realized with the support of the programme EPSILON of the Czech Republic Technology Agency TAČR, project No. TH03020368, titled "The optimisation of the shape and material of ground and mining machines research".

\section{REFEENCES}

Bílý I., Brabenec J.: (2012), The concept of monitoring and extraction of dolomite cemented silica sandstone in the Bilina mine, building on innovative alternatives to its use in the coarse and fine production of stonework SGEM Conference proceedings, Albena, Bulharsko.

Burda J., Veselý M., Řehoř M., Vilímek V.: (2017), Reconstruction of a large runout landslide in the Krušné hory Mts. (Czech Republic) Landslides, Journal of the International Consortium, DOI 10.1007/s10346-017-0881-0, ISSN 1612-510X, Springer (IF 0,35).

Dvořák Z., Mach K.: (1999), Deltaic deposits in the North Bohemian Brown Coal Basin and their documentacion in the Bílina opencast mine Acta Universitas Carolinae, 4/1999, 633-641, Praha.

Mach K.: (2002), Genesis of large scale syndepositional deformations of main coal seam Miocene Bílina delta, Most basin, Czech Republic Programme and abstracts of 5th European Coal Conference, 90. Mons-Frameries, Belgium.

Mach K.: (2003), Geologické aspekty výskytu pevných poloh na povrchovém lomu Bílina Zpravodaj hnědé uhlí, 3, s. 55-63, ISSN 1213-1660, VÚHU a.s., Most

Mach K: (2010), Application of boring technical parameters logging (geomechanical logging) during geological exploration on lignite opencast mine Prezentace, European Coal Conference, Darmstadt 2010

Mach K.: (2002a), Anomální stavba hlavní hnědouhelné sloje v prostoru miocénní bílinské delty a její geneze Zpráva, Prírodovědecká fakulta UK, Praha.

Mikoláš M. a kol.: (2006), Analýza dobývacích podmínek tvrdých poloh na lomu Bílina - I. a II. etapa Dílčí zpráva, VŠB-TU Ostrava, (2006-2007)

Pešek J. et al.: (2010), Terciérní pánve a ložiska hnědého uhlí České republiky Česká geologická služba, ISBN 978-80-7075-759-8, Praha.

Rajchl M.: (2006), Tectonosedimentary evolution of fluvio - deltaic systém of the Most Basin Geofond report, Prague.

Rajchl M., Uličný D.: (2000), Evolution of depocenter geometry in the Most Basin Geolines, No 10, p. $62-63$

Rojík P.: (1996), Geological setting, technological data and utilization of weathered coal Czech geological survey, p. 107-112, Prague.

Řehoř M.: (2013), Měření parametrů dobyvatelnosti skrývky při vrtném průzkumu na DNT a jejich sumarizace za období 2000-2013 do formy jednotné databáze Odborný posudek, VÚHU a.s., Most. 
Řehoř M., Moni V., Novák V., Kraus V., (2017), Schmidt P.: Results of long term testing of geological situation and excavator SChRs 1550-4x30/K109 parameters during the relocation to the position with the worse mining conditions in the Libous mine (the Most Basin) SGEM Conference Proceedings "Exploration and mining", VOLUME XVII, p. 765-772, ISBN 978-619-7105-00-1, ISSN 1314-2704, DOI:10.5593/sgem2017/13, Albena, Bulgaria.

Řehoř M., Moni V., Donát L.: (2016), The occurrence and main parameters of geological structures with excessive mining resistance in the Most Coal Basin area SGEM Conference Proceedings "Geology, hydrogeology engineering geology and geotechnics", VOLUME I, p. 619-263, ISBN 978-619-7105-55-1, ISSN 1314-2704, DOI:10.5593/sgem2016B11, Albena, Bulgaria.

Valášek V., Chytka L.: (2009), Velká kniha o hnědém uhlí G2 studio, Plzeň.

Vossen P.: (2006), Continuous mining World of mining journal, volume 58, p. 364-365, ISSN 1613-2408, 6.

Žd’árský J., Řehoř M.: (2007), Geomechanická charakteristika zemin v postupu dobývání skrývky na lokalitě Libouš Odborný posudek, VúHU a.s., Most.

Poltegol Instytut, (2018), Team of authors: Bucket wheel excavators operating under difficult mining conditions including unmineable inclusions and geological structures with excessive mining resistance BEWEXMIN project final report, Wroclaw, Poland.

Abstract. The Brown Coal Research Institute started the solving of the research project based on the optimisation of the shape and material of ground and mining machines in 2018. This research is necessary for increasing of efficiency of mining process in conditions of the Most Basin. The very important part of the research was the geological characteristic of the Most Basin main mining localities. Evaluation of the geological situation of the Bílina, Vršany and Libouš mines (mining of the overburden rocks in the ČSA mine finished) is the first stage of the solving of the project described in this article. The occurrence of sandy strata and the parameters of hard rocks are the most important parameters. The most important used laboratory analyses were the content of crystalline quartz, content of siderite, content of calcite and compressive strength. The location of the overburden cuts with similar mining conditions in different mining localities, very important for need of future research, is described in the end of this article.

Keywords: Excavator, cutting bodies, geology, hard structures, sands 